\title{
No Association between Vitiligo and Obesity: A Case-Control Study
}

\author{
Federica Dragoni ${ }^{a}$ Rossana Conti ${ }^{a}$ Simone Cazzaniga ${ }^{b}$ Roberta Colucci ${ }^{a}$ \\ Lisa Pisaneschi $^{\mathrm{a}} \quad$ Luigi Naldi $^{\mathrm{b}}$ Silvia Moretti ${ }^{\mathrm{a}}$ \\ a Department of Surgery and Translational Medicine, Section of Dermatology, University of Florence, Florence, and \\ ${ }^{b}$ GISED Study Centre, Ospedali Riuniti, Bergamo, Italy
}

\section{Significance of the Study}

- In this study, vitiligo did not appear to be associated with a high body mass index, in contrast to most other autoimmune diseases. This lack of an association could be due to a high expression of p53 and a high concentration of transforming growth factor- $\beta$ in vitiligo patients. Hence, in these patients, vitiligo could not lead to obesity.

\section{Keywords}

Vitiligo · Obesity · Case-control study · Body mass index

\section{Abstract}

Objective: The purpose of this study was to investigate the relationship between vitiligo and body mass index (BMI) to assess the possible association between vitiligo and obesity. Subjects and Methods: This was a case-control study on a total of 400 participants, i.e., 200 patients with vitiligo and 200 healthy volunteers. Medical assessments were performed by dermatologists using the modified Vitiligo European Task Force form. The height and weight of all of the participants were measured and used to calculate the BMI. Data were analyzed using multivariate logistic regression models. Adjustment for age and gender was carried out preliminarily in the case-control analysis, whereas a forward stepwise selection algorithm was used to assess which independent factors were associated with a $\mathrm{BMI} \geq 30$ or a $\mathrm{BMI}$ $\leq 18.5$. Results: Comparison of the vitiligo and control groups

\section{KARGER}

E-Mail karger@karger.com www.karger.com/mpp

\section{Karger} open access

This is an Open Access article licensed under the Creative Commons Attribution-NonCommercial-4.0 International License (CC BY-NC) (http://www.karger.com/Services/OpenAccessLicense), applicable to the online version of the article only. Usage and distribution for commercial purposes requires written permission. revealed the absence of a significant association. The multivariate analysis of factors associated with a high BMI $(\geq 30)$ in vitiligo patients showed a significant association between a high BMI and a sudden onset of vitiligo ( $p=0.021$; OR = 3.83; $95 \% \mathrm{Cl} 1.22-11.99)$ and the presence of inflammation and pruritus ( $p=0.031 ; \mathrm{OR}=3.26 ; 95 \% \mathrm{Cl} 1.11-9.57$ ). No significant association was observed in the analysis of factors associated with a low BMI $(\leq 18.5)$ in vitiligo patients. Conclusion: In this study, vitiligo did not appear to be associated with a high BMl; obesity might not be a risk factor for vitiligo, in contrast to most autoimmune diseases which are significantly associated with obesity.

(c) 2017 The Author(s) Published by S. Karger AG, Basel

\section{Introduction}

Vitiligo is an acquired, depigmenting skin disorder characterized by the appearance of well-delineated, white macules on the skin due to the selective disappearance of

Dr. Federica Dragoni

Department of Surgery and Translational Medicine Section of Dermatology, University of Florence

Viale Michelangiolo 41, IT-50125 Florence (Italy)

E-Mail federicadragoni@yahoo.it 
functional melanocytes in the epidermis [1]. Vitiligo affects people of all ages and both sexes equally, with a prevalence of approximately $0.5 \%$ of the world population [2]. Currently, vitiligo is considered a multifactorial disease with the specific involvement of autoimmunity, and thus vitiligo is regarded mainly as an autoimmune dermatosis $[3,4]$.

The association between many autoimmune or inflammatory diseases and obesity had been demonstrated $[5,6]$. Rheumatoid arthritis, multiple sclerosis, systemic lupus erythematosus, systemic sclerosis, psoriasis, and autoimmune thyroid diseases are some of the disorders linked to obesity and they can also be associated with vitiligo [5-9].

In obese people, fat cells produce high levels of leptin, a cytokine-like hormone that mediates the autocrine production of a wide variety of mediators including the proinflammatory cytokines tumor necrosis factor- $\alpha$ and interleukin-6 which contribute to creating a chronic inflammatory state capable of increasing the risk of autoimmune diseases [10-13].

In vitiligo, a significantly high expression of proinflammatory cytokines has been reported in lesional and perilesional skin. These are thought to be essential regulators of melanocyte dysfunction and death. Contradictory results have been observed at a systemic level [14-17]. Recently, elevated serum interleukin-17A, transforming growth factor- $\beta 1$, and interleukin-21 levels have been identified at a systemic level in vitiligo patients [18].

Karadag et al. [19] showed that patients with vitiligo have a higher insulin resistance, a higher LDL/HDL ratio, and a higher systolic blood pressure. A recent report provided information on the reduction of some cardiovascular risk factors in patients with vitiligo. However, the relationship between vitiligo and cardiovascular disease is not yet clear and no association between vitiligo and obesity has ever been documented in a case-control study [20].

The purpose of this study was to investigate the relationship between vitiligo and body mass index (BMI) to assess the possible association between vitiligo and obesity.

\section{Subjects and Methods}

A case-control study was performed at our specialized vitiligo outpatient service in Florence, Italy, during a 3-year period (March 2012 to March 2015). A total of 400 Caucasian participants were included in this study, i.e., 200 patients with vitiligo and 200 healthy volunteers. Of the 200 vitiligo patients, 92 were males and
108 females, with ages ranging between 14 and 75 years. In doubtful cases, a histological examination was performed to confirm the diagnosis. This study was conducted according to the principles of the Declaration of Helsinki, and written informed consent was obtained from each patient for retrospective data collection. The medical assessment involved natural and Wood's light examinations consistent with the modified Vitiligo European Task Force form [21]. Based on the Vitiligo European Task Force, a patient's palm corresponding to $1 \%$ of body surface area was used to calculate the total vitiligo extension [22]. Exclusion criteria were segmental vitiligo, doubtful diagnosis of vitiligo with no histological evidence, and no written informed consent.

The control group included 200 healthy volunteers (92 males and 108 females, aged between 17 and 76 years, with no history of dermatological or systemic disease and who were age and sex matched to the vitiligo patients.

The height and weight of all of the participants were measured and used to calculate the BMI (weight in $\mathrm{kg}$ divided by height in $\mathrm{m}$ squared $\left[\mathrm{kg} / \mathrm{m}^{2}\right]$ ). All of the participants were measured for height and weight and the BMI was calculated. BMI was taken as an index of obesity (BMI $\geq 30$ was the obesity marker and BMI $\leq 18.5$ was the underweight marker) and analyzed its possible relationship with the following clinical features of vitiligo: age at onset, vitiligo onset, modality of onset, growth of lesions, disease activity, total disease extension, Koebner's phenomenon, and inflammation/ pruritus.

A personal history of cardiovascular disease, cancer, autoimmune disease (discoid lupus erythematosus, alopecia areata, autoimmune thyroiditis and/or gastritis, celiac disease, type 1 diabetes, Addison's disease, and scleroderma) and psoriasis were all evaluated. In addition, corticosteroid therapy, immunosuppressive therapy, and smoking habit were assessed. All of these data were obtained from paper and computerized medical records.

\section{Statistical Analysis}

Data were analyzed using multivariate logistic regression models. Adjustment for age (in quintiles) and gender was carried out preliminarily in the case-control analysis, whereas a forward stepwise selection algorithm was then used to assess which independent factors were associated with a BMI $\geq 30$ or a BMI $\leq 18.5$. The effect of selected factors was expressed in terms of OR with $95 \% \mathrm{CI}$ and $p$ values. $p<0.05$ was considered statistically significant.

\section{Results}

The general data for the cases and controls are summarized in Appendix 1 . The mean $( \pm \mathrm{SD})$ and median age of the patients was $43.7 \pm 16$ and 45 years, respectively, and that of the controls was $44.3 \pm 16.1$ and 48.0 years, respectively. Comparison of the vitiligo and control groups revealed the absence of a significant association (Table 1). A crude analysis of the factors associated with a high BMI ( $\geq 30$, obese) in vitiligo patients had a highlighted significant association between a high BMI and sudden onset of vitiligo (appearance of all of the patches present at the time of the visit in $<1$ month) ( $p=0.028)$, the presence of in- 
flammation and pruritus in vitiligo lesions $(p=0.037)$, and a personal history of cardiovascular disease $(p=0.003)$ (Table 2). Multivariate analysis revealed a significant association between a high BMI and sudden onset of vitiligo $(p=0.021$; OR $=3.83 ; 95 \%$ CI $1.22-11.99)$ and the presence of inflammation and pruritus in vitiligo lesions ( $p=$ 0.031; OR = 3.26; 95\% CI 1.11-9.57).

No significant association was observed in the analysis of factors associated with a low BMI $(\leq 18.5)$ in vitiligo patients (Table 3).

\section{Discussion}

In this study, the high BMI was significantly associated with the sudden onset of vitiligo, inflammation, and pruritus. Obesity is a proinflammatory condition in which hypertrophic adipocytes and adipose tissue-resident cells contribute to increase circulating levels of proinflammatory cytokines [23]. Leptin plays a pivotal role that can reduce the function and expansion of regulatory $\mathrm{T}$ cells and thereby amplifies inflammatory processes through the recruitment of CD8+ Th1 lymphocytes, mast cells, and macrophages and stimulates the release of proinflammatory cytokines and interleukin-2 [6]. Therefore, this chronic low-grade systemic inflammation can explain the association between a high BMI and the presence of inflammation/pruritus in vitiligo macules and possibly also the sudden onset of the disease.

However, vitiligo did not seem to be associated with a high BMI, in contrast to most autoimmune diseases which are significantly associated with obesity [6]. Increasing evidence suggests that the p53 tumor suppressor protein which also has important regulatory functions in cell growth/differentiation and metabolism is overexpressed in both lesional and nonlesional epidermis of patients with vitiligo [24-26]. A recent in vivo study showed that p53 exerts a suppressive effect on white adipocyte differentiation in both mouse and human cells, suggesting that this protein has a potential protective effect against diet-induced obesity [27]. The same study highlighted how p53 is implicated in proper brown adipose tissue differentiation which seemingly is protective against obesity [27]. Thus, it is conceivable that in vitiligo patients p53 is overexpressed in adipose tissue as well as in the skin, explaining our results at least in part.

An additional explanation of our results may be that in vitiligo there is a high systemic concentration of transforming growth factor- $\beta$, which is known to be a potent
Table 1. Case-control analysis

\begin{tabular}{|c|c|c|c|c|c|}
\hline & \multicolumn{2}{|c|}{$\begin{array}{l}\text { Vitiligo } \\
(n=200)\end{array}$} & \multicolumn{2}{|c|}{$\begin{array}{l}\text { Control } \\
(n=200)\end{array}$} & \multirow[t]{2}{*}{$\begin{array}{l}p \\
\text { value }\end{array}$} \\
\hline & $n$ & $\%$ & $n$ & $\%$ & \\
\hline Age, years & 43.7 & 16.1 & 44.4 & 16.2 & \\
\hline$<35$ & 65 & 32.5 & 61 & 30.5 & 0.544 \\
\hline $35-49$ & 53 & 26.5 & 63 & 31.5 & \\
\hline $50+$ & 82 & 41.0 & 76 & 38.0 & \\
\hline \multicolumn{6}{|l|}{ Sex } \\
\hline Female & 108 & 54.0 & 108 & 54.0 & 1 \\
\hline Male & 92 & 46.0 & 92 & 46.0 & \\
\hline BMI & 23.8 & 3.5 & 23.6 & 4.3 & \\
\hline$\leq 18.5$ & 29 & 14.5 & 33 & 16.5 & 0.667 \\
\hline $18.6-29.9$ & 153 & 76.5 & 154 & 77.0 & \\
\hline$\geq 30.0$ & 18 & 9.0 & 13 & 6.5 & \\
\hline \multicolumn{6}{|l|}{ Type of vitiligo onset } \\
\hline Early (age $<18$ years) & 49 & 24.6 & - & - & - \\
\hline Late $(>18$ years $)$ & 150 & 75.4 & - & - & \\
\hline \multicolumn{6}{|l|}{ Speed of vitiligo onset } \\
\hline Sudden & 83 & 42.3 & - & - & - \\
\hline Gradual & 113 & 57.7 & - & - & \\
\hline \multicolumn{6}{|c|}{ Growth of vitiligo lesions } \\
\hline Absent & 12 & 6.1 & - & - & - \\
\hline Slow & 145 & 73.6 & - & - & \\
\hline Rapid & 40 & 20.3 & - & - & \\
\hline \multicolumn{6}{|l|}{ Inflammation/pruritus } \\
\hline No & 147 & 75.4 & - & - & - \\
\hline Yes & 48 & 24.6 & - & - & \\
\hline Total vitiligo extension, $\%$ & 7.6 & 16.7 & & & \\
\hline$<1.0$ & 50 & 29.1 & - & - & - \\
\hline $1.0-4.9$ & 71 & 41.3 & - & - & \\
\hline$\geq 5.0$ & 51 & 29.7 & - & - & \\
\hline \multicolumn{6}{|l|}{ Disease activity } \\
\hline Active & 104 & 53.6 & - & - & - \\
\hline Borderline & 34 & 17.5 & - & - & \\
\hline Stable & 56 & 28.9 & - & - & \\
\hline \multicolumn{6}{|l|}{ Koebner's phenomenon } \\
\hline No & 99 & 51.6 & - & - & - \\
\hline Yes & 93 & 48.4 & - & - & \\
\hline \multicolumn{6}{|c|}{ Personal history of cardiovascular disease } \\
\hline No & 176 & 88.0 & 164 & 82.0 & 0.193 \\
\hline Yes & 24 & 12.0 & 36 & 18.0 & \\
\hline \multicolumn{6}{|c|}{ Personal history of cancer } \\
\hline No & 191 & 96.0 & 184 & 92.0 & 0.295 \\
\hline Yes & 8 & 4.0 & 16 & 8.0 & \\
\hline \multicolumn{6}{|c|}{ Personal history of autoimmune disease } \\
\hline No & 165 & 82.5 & 194 & 97.0 & 0.101 \\
\hline Yes & 35 & 17.5 & 6 & 3.0 & \\
\hline \multicolumn{6}{|l|}{ Personal history of psoriasis } \\
\hline No & 190 & 95.0 & 189 & 94.5 & 0.823 \\
\hline Yes & 10 & 5.0 & 11 & 5.5 & \\
\hline \multicolumn{6}{|l|}{ Smoker } \\
\hline No & 108 & 60.0 & 142 & 71.0 & 0.224 \\
\hline Yes & 72 & 40.0 & 58 & 29.0 & \\
\hline \multicolumn{6}{|l|}{ Corticosteroid therapy } \\
\hline No & 198 & 99.0 & 195 & 97.5 & 0.449 \\
\hline Yes & 2 & 1.0 & 5 & 2.5 & \\
\hline \multicolumn{6}{|c|}{ Immunosuppressive therapy } \\
\hline No & 200 & 100.0 & 197 & 98.5 & 0.248 \\
\hline Yes & 0 & 0.0 & 3 & 1.5 & \\
\hline
\end{tabular}

Med Princ Pract 2017;26:421-426 DOI: $10.1159 / 000481436$ 
Table 2. Crude analysis of factors associated with a high BMI $(\geq 30)$ in vitiligo patients

\begin{tabular}{|c|c|c|c|c|}
\hline & \multirow[t]{2}{*}{$N$} & \multicolumn{2}{|c|}{$\mathrm{BMI} \geq 30$} & \multirow{2}{*}{$\begin{array}{l}p \\
\text { value }\end{array}$} \\
\hline & & $n$ & $\%$ & \\
\hline \multicolumn{5}{|l|}{ Age } \\
\hline$<35$ years & 126 & 4 & 3.2 & \multirow[t]{3}{*}{0.055} \\
\hline $35-49$ years & 116 & 10 & 8.6 & \\
\hline $50+$ years & 158 & 17 & 10.8 & \\
\hline \multicolumn{5}{|l|}{ Sex } \\
\hline Female & 216 & 11 & 5.1 & \multirow[t]{2}{*}{0.031} \\
\hline Male & 184 & 20 & 10.9 & \\
\hline \multicolumn{5}{|l|}{ Type of vitiligo onset } \\
\hline Early (age < 18 years) & 49 & 2 & 4.1 & \multirow[t]{2}{*}{0.251} \\
\hline Late (age $>18$ years) & 150 & 16 & 10.7 & \\
\hline \multicolumn{5}{|l|}{ Speed of vitiligo onset } \\
\hline Sudden & 83 & 12 & 14.5 & \multirow[t]{2}{*}{0.028} \\
\hline Gradual & 113 & 6 & 5.3 & \\
\hline \multicolumn{5}{|l|}{ Growth of vitiligo lesions } \\
\hline Absent & 12 & 0 & 0.0 & \multirow[t]{3}{*}{0.746} \\
\hline Slow & 145 & 15 & 10.3 & \\
\hline Rapid & 40 & 3 & 7.5 & \\
\hline \multicolumn{5}{|l|}{ Inflammation/pruritus } \\
\hline No & 147 & 9 & 6.1 & \multirow[t]{2}{*}{0.037} \\
\hline Yes & 48 & 8 & 16.7 & \\
\hline \multicolumn{5}{|l|}{ Total vitiligo extension } \\
\hline$<1.0 \%$ & 50 & 4 & 8.0 & \multirow[t]{3}{*}{1} \\
\hline $1.0-4.9 \%$ & 71 & 6 & 8.5 & \\
\hline$\geq 5.0 \%$ & 51 & 5 & 9.8 & \\
\hline \multicolumn{5}{|l|}{ Disease activity } \\
\hline Active & 104 & 11 & 10.6 & \multirow[t]{3}{*}{0.456} \\
\hline Borderline & 34 & 1 & 2.9 & \\
\hline Stable & 56 & 5 & 8.9 & \\
\hline \multicolumn{5}{|l|}{ Koebner's phenomenon } \\
\hline No & 99 & 9 & 9.1 & 0.695 \\
\hline Yes & 93 & 7 & 7.5 & \\
\hline Personal history of cardic & $r$ disec & & & \\
\hline No & 340 & 20 & 5.9 & 0.003 \\
\hline Yes & 60 & 11 & 18.3 & \\
\hline Personal history of cance & & & & \\
\hline No & 375 & 30 & 8.0 & 0.240 \\
\hline Yes & 24 & 0 & 0.0 & \\
\hline Personal history of autoin & diseas & & & \\
\hline No & 359 & 30 & 8.4 & 0.348 \\
\hline Yes & 41 & 1 & 2.4 & \\
\hline Personal history of psoria & & & & \\
\hline No & 379 & 29 & 7.7 & 0.673 \\
\hline Yes & 21 & 2 & 9.5 & \\
\hline Smoker & & & & \\
\hline No & 250 & 16 & 6.4 & 0.210 \\
\hline Yes & 130 & 13 & 10.0 & \\
\hline Corticosteroid therapy & & & & \\
\hline No & 393 & 31 & 7.9 & 1 \\
\hline Yes & 7 & 0 & 0.0 & \\
\hline Immunosuppressive ther & & & & \\
\hline No & 397 & 30 & 7.6 & 0.215 \\
\hline Yes & 3 & 1 & 33.3 & \\
\hline
\end{tabular}

Table 3. Analysis of factors associated with a low BMI $(\leq 18.5)$ in vitiligo patients

\begin{tabular}{|c|c|c|c|c|}
\hline & \multirow[t]{2}{*}{$N$} & \multicolumn{2}{|c|}{$\mathrm{BMI}<20$} & \multirow{2}{*}{$\begin{array}{l}p \\
\text { value }\end{array}$} \\
\hline & & $n$ & $\%$ & \\
\hline \multicolumn{5}{|l|}{ Age } \\
\hline$<35$ years & 126 & 29 & 23.0 & \multirow[t]{3}{*}{$<0.001$} \\
\hline $35-49$ years & 116 & 23 & 19.8 & \\
\hline $50+$ years & 158 & 10 & 6.3 & \\
\hline \multicolumn{5}{|l|}{ Sex } \\
\hline Female & 216 & 49 & 22.7 & \multirow[t]{2}{*}{$<0.001$} \\
\hline Male & 184 & 13 & 7.1 & \\
\hline \multicolumn{5}{|l|}{ Type of vitiligo onset } \\
\hline Early (age < 18 years) & 49 & 12 & 24.5 & \multirow[t]{2}{*}{0.023} \\
\hline Late (age $>18$ years) & 150 & 17 & 11.3 & \\
\hline \multicolumn{5}{|l|}{ Speed of vitiligo onset } \\
\hline Sudden & 83 & 11 & 13.3 & \multirow[t]{2}{*}{0.602} \\
\hline Gradual & 113 & 18 & 15.9 & \\
\hline \multicolumn{5}{|l|}{ Growth of vitiligo lesions } \\
\hline Absent & 12 & 2 & 16.7 & \multirow[t]{3}{*}{0.639} \\
\hline Slow & 145 & 23 & 15.9 & \\
\hline Rapid & 40 & 4 & 10.0 & \\
\hline \multicolumn{5}{|l|}{ Inflammation/pruritus } \\
\hline No & 147 & 25 & 17.0 & \multirow[t]{2}{*}{0.143} \\
\hline Yes & 48 & 4 & 8.3 & \\
\hline \multicolumn{5}{|l|}{ Total vitiligo extension } \\
\hline$<1.0 \%$ & 50 & 8 & 16.0 & \multirow[t]{3}{*}{0.254} \\
\hline $1.0-4.9 \%$ & 71 & 13 & 18.3 & \\
\hline$\geq 5.0 \%$ & 51 & 4 & 7.8 & \\
\hline \multicolumn{5}{|l|}{ Disease activity } \\
\hline Active & 104 & 16 & 15.4 & \multirow[t]{3}{*}{0.843} \\
\hline Borderline & 34 & 4 & 11.8 & \\
\hline Stable & 56 & 9 & 16.1 & \\
\hline \multicolumn{5}{|l|}{ Koebner phenomenon } \\
\hline No & 99 & 13 & 13.1 & 0.556 \\
\hline Yes & 93 & 15 & 16.1 & \\
\hline Personal history of cardic & $\mathrm{r}$ dise & & & \\
\hline No & 340 & 59 & 17.4 & 0.015 \\
\hline Yes & 60 & 3 & 5.0 & \\
\hline Personal history of cance & & & & \\
\hline No & 375 & 59 & 15.7 & 1 \\
\hline Yes & 24 & 3 & 12.5 & \\
\hline Personal history of autoin & diseas & & & \\
\hline No & 359 & 54 & 15.0 & 0.454 \\
\hline Yes & 41 & 8 & 19.5 & \\
\hline Personal history of psoria & & & & \\
\hline No & 379 & 59 & 15.6 & 1 \\
\hline Yes & 21 & 3 & 14.3 & \\
\hline Smoker & & & & \\
\hline No & 250 & 40 & 16.0 & 0.969 \\
\hline Yes & 130 & 21 & 16.2 & \\
\hline Corticosteroid therapy & & & & \\
\hline No & 393 & 60 & 15.3 & 0.297 \\
\hline Yes & 7 & 2 & 28.6 & \\
\hline Immunosuppressive ther & & & & \\
\hline No & 397 & 62 & 15.6 & 1 \\
\hline Yes & 3 & 0 & 0.0 & \\
\hline
\end{tabular}

Dragoni/Conti/Cazzaniga/Colucci/ Pisaneschi/Naldi/Moretti 
inhibitor of white adipose tissue differentiation $[18,28$, 29].

Thus, it is conceivable that the high expression of $\mathrm{p} 53$ and the high concentration of transforming growth factor- $\beta$ can contribute to the absence of obesity in our patients, as opposed to other autoimmune diseases.

A possible limitation of this study was noninvestigation of p53 and transforming growth factor- $\beta$, which could have affected the findings.

\section{Conclusion}

In this study, in contrast with most autoimmune diseases which are significantly associated with obesity, vitiligo did not appear to be related to a high BMI. Therefore, neither a high BMI nor obesity represents a feature of vitiligo in these patients and this seems to be an unusual autoimmune disease.

\section{Appendix 1}

General characteristics of the case and control groups.

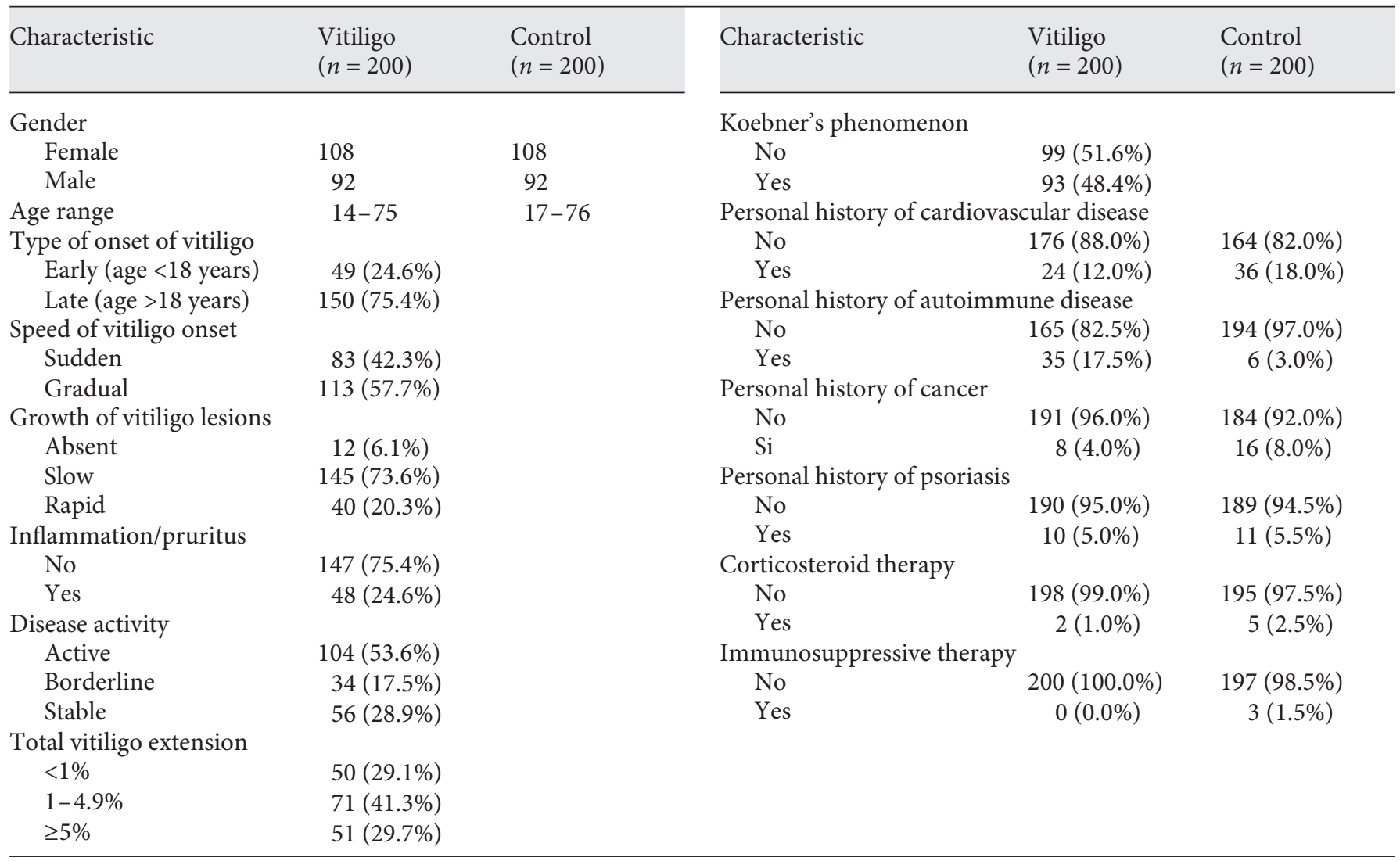




\section{References}

1 Ezzedine K, Eleftheriadou V, Whitton M, et al: Vitiligo. Lancet 2015;386:74-84.

2 Conti R, Colucci R, Arunachalam M, et al: Hair and scalp disorders in a Tuscan pediatric dermatological outpatient clinic: a clinical and epidemiological evaluation. Med Princ Pract 2016;25:67-71.

3 Ongenae K, Van Geel N, Naeyaert JM: Evidence for an autoimmune pathogenesis of vitiligo. Pigment Cell Res 2003;16:90-100.

4 Colucci R, Dragoni F, Moretti S: Oxidative stress and immune system in vitiligo and thyroid diseases. Oxid Med Cell Longev 2015; 2015:631927.

5 Al-Herz A, Al-Awadhi A, Saleh K, et al: Low prevalence of modules in rheumatoid arthritis patients in Kuwait: a description and a comparison of patients from the Kuwait Registry for Rheumatic Diseases. Med Princ Pract 2017;26:152-156.

6 Procaccini C, Carbone F, Galgani M, et al: Obesity and susceptibility to autoimmune diseases. Expert Rev Clin Immunol 2011;7: 287-294.

7 Versini M, Jeandel PY, Rosenthal E, et al: Obesity in autoimmune diseases: not a passive bystander. Autoimmun Rev 2014;13: 981-1000.

8 Winsz-Szczotka K, Kuznik-Trocha K, Komosinska-Vassev K, et al: Relationship between adiponectin, leptin, IGF-1 and total lipid peroxides plasma concentrations in patients with systemic sclerosis: possible role in disease development. Int J Rheum Dis 2016;19:706714.

9 Arunachalam M, Dragoni F, Colucci R, et al: Non-segmental vitiligo and psoriasis comorbidity - a case-control study in Italian patients. J Eur Acad Dermatol Venereol 2014; 28:433-437.

10 Bulló M, García-Lorda P, Megias I, et al: Systemic inflammation, adipose tissue tumor necrosis factor, and leptin expression. Obes Res 2003; 11:525-531.
11 Procaccini C, Pucino V, Mantzoros CS, et al: Leptin in autoimmune diseases. Metabolism 2015;64:92-104.

12 Fidan-Yaylali G, Yaylali YT, Erdogan Ç, et al: The association between central adiposity and autonomic dysfunction in obesity. Med Princ Pract 2016;25:442-448.

13 Bagir GS, Bakiner OS, Bozkirli E, et al: Body mass index below obesity threshold implies similar cardiovascular risk among various polycystic ovary syndrome phenotypes. Med Princ Pract 2016;25:61-66.

14 Camara-Lemarroy CR, Salas-Alanis JC: The role of tumor necrosis factor- $\alpha$ in the pathogenesis of vitiligo. Am J Clin Dermatol 2013; 14:343-350.

15 Moretti S, Spallanzani A, Amato L, et al: New insights into the pathogenesis of vitiligo: Imbalance of epidermal cytokines at sites of lesions. Pigment Cell Res 2002;15:87-92.

16 Singh S, Singh U, Pandey SS: Serum concentration of IL-6, IL-2, TNF- $\alpha$, and IFN $\gamma$ in vitiligo patients. Indian J Dermatol 2012;57:1214.

17 Yu HS, Chang KL, Yu CL, et al: Alterations in IL-6, IL-8, GM-CSF, TNF-alpha, and IFNgamma release by peripheral mononuclear cells in patients with active vitiligo. J Invest Dermatol 1997;108:527-529.

18 Zhou L, Shi YL, Li K, et al: Increased circulating Th17 cells and elevated serum levels of TGF-beta and IL-21 are correlated with human non-segmental vitiligo development. Pigment Cell Melanoma Res 2015;28:324329.

19 Karadag AS, Tutal E, Ertugrul DT: Insulin resistance is increased in patients with vitiligo. Acta Derm Venereol 2011;9:541-544.
20 Rodríguez-Martín M, de Paz NM, Mehtani P, et al: Patients with vitiligo present fewer cardiovascular risk factors: results from a casecontrol study. J Eur Acad Dermatol Venereol 2013;27:124-125.

21 Moretti S, Arunachalam M, Colucci R, et al: Autoimmune markers in vitiligo patients appear correlated with obsession and phobia. J Eur Acad Dermatol Venereol 2012;26:861867.

22 Taïeb A, Picardo M; VETF Members: The definition and assessment of vitiligo: a consensus report of the Vitiligo European Task Force. Pigment Cell Res 2007;20:27-35.

23 Makki K, Froguel P, Wolowczuk I: Adipose tissue in obesity-related inflammation and insulin resistance: cells, cytokines, and chemokines. ISRN Inflamm 2013;2013:139239.

24 Vousden KH, Prives C: Blinded by the light: the growing complexity of p53. Cell 2009;137: 413-431.

25 Schallreuter KU, Behrens-Williams S, Khaliq $\mathrm{TP}$, et al: Increased epidermal functioning wild-type p53 expression in vitiligo. Exp Dermatol 2003;12:268-277.

26 Salem MM, Shalbaf M, Gibbons NC, et al: Enhanced DNA binding capacity on up-regulated epidermal wild-type p53 in vitiligo by $\mathrm{H} 2 \mathrm{O} 2$-mediated oxidation: a possible repair mechanism for DNA damage. FASEB J 2009; 23:3790-3807.

27 Molchadsky A, Ezra O, Amendola PG, et al: p53 is required for brown adipogenic differentiation and has a protective role against diet-induced obesity. Cell Death Differ 2013;20: 774-783.

28 Choy L, Derynck R: Transforming growth factor-beta inhibits adipocyte differentiation by Smad3 interacting with CCAAT/enhancer-binding protein (C/EBP) and repressing C/ EBP transactivation function. J Biol Chem 2003;278:9609-9619.

29 Ali AT, Hochfeld WE, Myburgh R, et al: Adipocyte and adipogenesis. Eur J Cell Biol 2013; 92:229-236. 